\title{
氷盤下にトラップされた流出原油の 水盤中への临透 \\ PERMEATION OF SPILLED CRUDE OIL INTO SEA ICE SHEET
}

\author{
大島香織 ${ }^{1} \cdot$ 大塚夏彦 $^{2} \cdot$ 石川博基 $^{3} \cdot$ 高橋伸次郎 ${ }^{4} \cdot$ 渡部靖憲 ${ }^{5} \cdot$ 橘治国 ${ }^{5} \cdot$ 佐伯浩 ${ }^{6}$ \\ Kaori OHSHIMA, Natsuhiko OHTSUKA, Hiroki ISHIKAWA, Shinjiro TAKAHASI, \\ Yasunori WATANABE, Naokuni TATIBANA and Hiroshi SAEKI \\ 1 学生会員 北海道大学大学院 工学研究科（T060-0813 札幌市北区北 13 条西 8 丁目) \\ ${ }^{2}$ 正会員 北日本港湾コンサルタント(侏、3 学生会員 北海道大学工学部 土木工学科 \\ ${ }^{4}$ 正会員 西村組㑣、 ${ }^{5}$ 正会員 工博 北海道大学大学院助教授 \\ 6フェロー 工博 北海道大学大学院教授
}

\begin{abstract}
Development of oil and gas deposits off Sakhalin's northern coast in the sea of Okhotsk are currently under way. An accident involving a spill of crude oil could be expected to affect the environment and economy of the Hokkaido's Okhotsk coast. If the oil spill occurred in winter season due to the accidents of pipeline, oil tanker and oil rigs, spilled oil would be trapped under the ice floes. If the operation for recovery of spilled oil will be late, spilled oil under the ice floes will be trapped in the ice sheet. In this paper the authors report the behavior of spilled oil trapped under ice sheet and the permeation of spilled oil into ice sheet.
\end{abstract}

Key Words : Spilled oil, crude oil, ice sheet, Sakhalin, permeation

\section{1.はじめに}

現在、サハリン北東沿岸オホーツク海において石 油・天然ガス開発が行われており、今年の夏には実 際に生産も開始される。海洋における原油掘削が始 められて以来、世界中で多くの流出事故が発生して いる。1997 年に起きたナホトカ号の事故も記憶に 新しい。これら原油流出事故の主な原因には、暴噴 や操作ミス等による火災、海底パイプラインの損傷、 タンカー事故、あるいは生産用海洋構造物そのもの の破壊などがある。

現在開発が行われているオホーツク海は、冬期に なると一面流氷に覆われるという特有の自然条件を 有する。この流氷の存在により、原油流出事故が発 生する危険性がさらに増大寸る事も考えられる。ま
た、サハリン東部沿岸で輸送タンカーの事故等の原 油の流出事故が発生すると、流出した原油は海流や 流水とともに北海道のオホーツク海沿岸に到達する 可能性もある。

特に冬期に流出事故が起きると流水などの氷盤下 面に原油が流出する可能性がある。このような場合 の原油の回収は通常の温暖な海域で事故が起こった 時よりも困難となると思われる。その原因の一つは、 流出後さらに氷盤が成長すると流出した原油がサン ドイッチ状に氷盤中に閉じ込められてしまうためで ある。このような状態になると、原油は氷盤中のブ ラインなどに沴入していくと考えられる。

本研究の目的は、冬期流水下面にトラップされた 流出原油の挙動と、さらに氷盤が成長した時の原油 
の水盤中への沴入のメカニズムを明らかにすること である。

\section{2. 筫透実験}

水盤中に原油がトラップされた時、原油は水盤中 のブラインや空隙などへ渗透することが考えられる。 その滲透量を測定するために各種実験を行った。

\section{（1）実䀫 I}

実験 I として、水槽に塩分濃度の異なる海水を入 れ、海水盤を作成しその下に一定量の原油を注入し、 さらに海水盤を成長させた後、水槽より水盤を取り 出す。

水盤を取り出し、水平方向に 4 層または 5 層に分 けて切断し、それぞれの層の氷を溶かし原油と海水 に分け、水盤中への原油の含有率の鉛直分布を求め た。また、氷盤の塩分濃度を測定し、既研究成果 ${ }^{1)}$ より透水係数を求め、水盤への原油の含有率と透水 係数の関係を明らかにした。

\section{a) 実験方法}

実験には 2 種類の水槽を用いて行った。1つ目の 水槽（以降、水槽 $\mathrm{A}$ とする）は、繸 $80 \times$ 横 $80 \times$ 深 さ $90 \mathrm{~cm}$ の耐水べニア水槽内壁部に $50 \mathrm{~mm}$ 厚の発泡材 を入れ、その内側に透明のビニール箱を入れた物を 用いた。この水槽には氷厚増加による体積増加の影 響を減らすためと断熱材の役割をもたすため変形し やすい発泡材 $(50 \mathrm{~mm})$ を内側に用いている。この水 槽の一部は外からも水槽の内部が観察できるような 構造となっている（図一-1)。

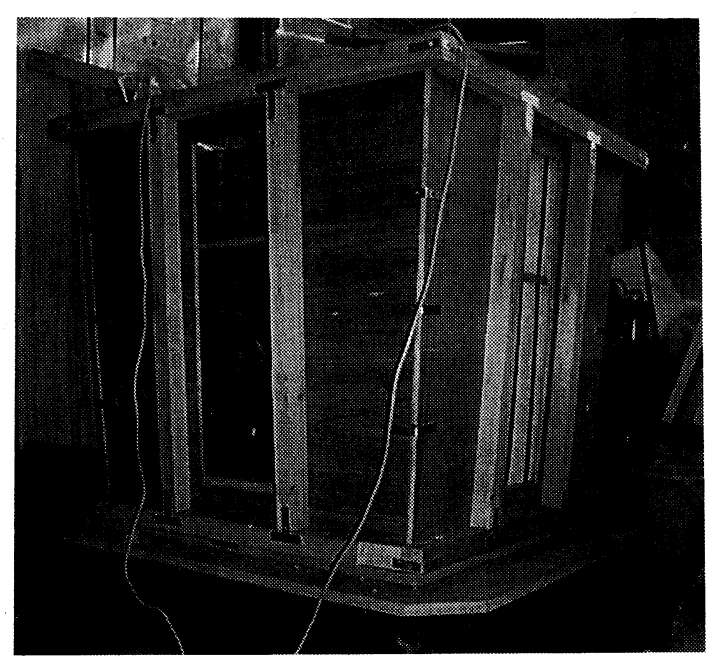

図-1 実験水槽 (水槽 A)
凍結時は、この箱の回りを $100 \mathrm{~mm}$ 厚の断熱材で覆 い側面、底面からの熱の出入を抑制する。

2 つ目の水槽は、プラスチック製容器（縦 $32 \times$ 横 $71 \times$ 深さ $28 \mathrm{~cm}$ ）（以降、水槽 $\mathrm{B}$ とする）である。実 験時にはこの水槽の周りに断熱材を巻いて側面など からの熱の出入りを抑制した。

実験は異なる濃度の海水を用いて CASE1〜 5 の 5 パターンについて行った。

CASE1 の実験は水槽 A を用いて行った。用いた海 水の塩分濃度は $33 \%$ である。凍結時の室温は始め $-10^{\circ} \mathrm{C}$ 、その後 $-5^{\circ} \mathrm{C} に し て$ 行った。

CASE2〜 4 に実験には水槽 B を用いた。海水の塩 分濃度は CASE 2 が $25 \%$ 、CASE 3 が $30 \%$ 、CASE 4 が 34\%である。これらの海水を満たした水槽を、室温 - $5{ }^{\circ} \mathrm{C}$ の低温室に入れ実験した。

CASE1〜4 は水厚が $7 〜 10 \mathrm{~cm}$ になった時点で原油 注入装置（図一2）を用い原油を氷盤下面に注入し た。その後水盤を成長させた。原油注入量は CASE2 〜4 は 180m1、CASE1 は測定できなかった。これら の実験では原油の注入量が少なく氷盤下面にトラッ プされた全ての原油が氷盤中に渗透してしまったこ ともあり、CASE5 は原油の注入量を増やして実験を 行った。

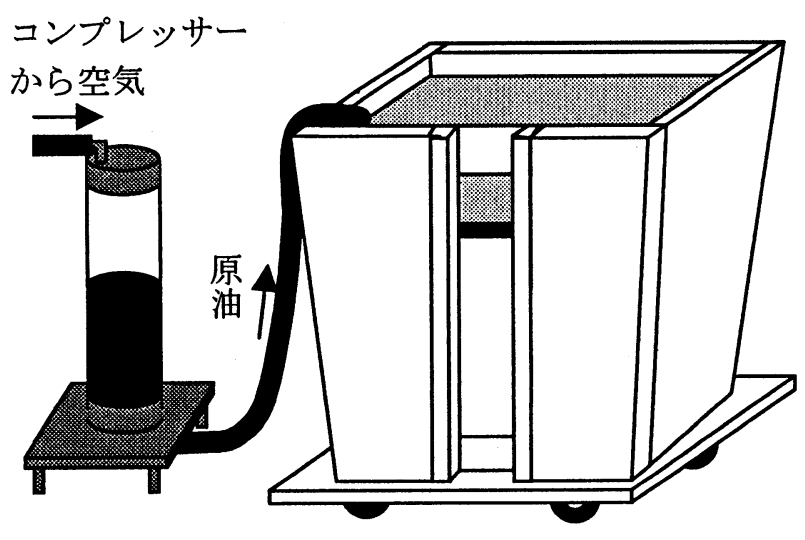

图-2 原油注入装置

CASE5 は水槽 A を用い海水の塩分濃度 $33 \%$ で水 盤を作成した。水厚が約 $15 \mathrm{~cm}$ になった時点で氷盤

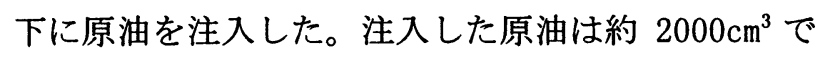
ある。注入前の原油の粘度は、 $1.73 \mathrm{dPa} \cdot \mathrm{s} 、$ 密度 $0.8725 \mathrm{~g} / \mathrm{cm}^{3}\left(-5^{\circ} \mathrm{C}\right)$ であった。その後水盤をさらに 成長させた。氷盤が約 $30 \mathrm{~cm}$ 程度になった時点で水 槽から取り出した。

CASE5 の室温は、他の実験との関係もありほとん どが- $25^{\circ} \mathrm{C} て ゙$ 行わなければならなかった。原油注入 
時は - $5^{\circ} \mathrm{C} \sim-10^{\circ} \mathrm{C}$ 程度にした。温度がかなり低い 状態での実験であったため、水盤下面の形状は不均 一な結晶の状態であった。そのため注入時の水盤下 面を平らにするため、原油注入前に氷盤を一度取り だし、底面を削った後氷盤を再び水槽に戻した。そ の際に、海水の塩分濃度も再び $33 \%$ に調整した。

また、いずれの実験でも水盤の隅に自由水面を 設けることにより氷盤下面への圧力がかからない ようにした。

\section{b) 水盤の塩分漞度}

水盤が成長した後に氷盤ごと水槽から取り出した (図-3)。

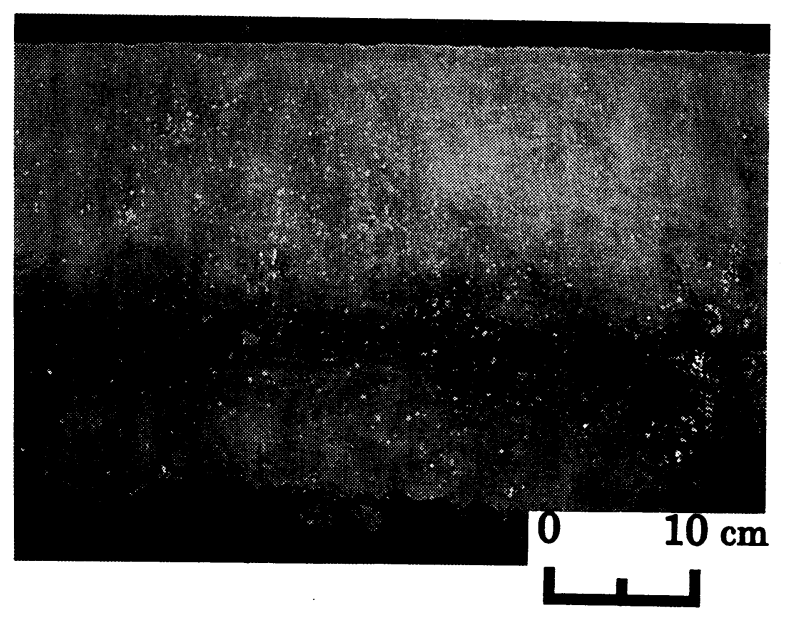

図-3 水槽から取り出した海氷盤断面（CASE5）

それぞれの害験での氷盤の塩分濃度を測定した。 表 -1 は CASE1 4 の平均塩分濃度、表 -2 には CASE5 の各層ごとの平均塩分濃度を示す。

丧 -1 水盤の塩分濃度 (CASE1〜4)

\begin{tabular}{|c|c|c|}
\hline & $\begin{array}{c}\text { 海水塩分濃度 } \\
(\%)\end{array}$ & $\begin{array}{c}\text { 水盤塩分濃度 } \\
(\%)\end{array}$ \\
\hline CASE1 & 33 & 6.40 \\
\hline CASE2 & 25 & 8.05 \\
\hline CASE3 & 30 & 10.33 \\
\hline CASE4 & 34 & 8.71 \\
\hline
\end{tabular}

表 -2 水盤の塩分濃度 (CASE5)

\begin{tabular}{|c|c|c|}
\hline CASE5 & $\begin{array}{c}\text { 海水塩分濃度 } \\
(\% \text { ) }\end{array}$ & $\begin{array}{c}\text { 水盤塩分濃度 } \\
(\% \text { o }\end{array}$ \\
\hline 1層 $(5 \mathrm{~cm})$ & 33 & 2.1 \\
\hline 2層 $(5 \mathrm{~cm})$ & 33 & 2.9 \\
\hline 3層 $(5 \mathrm{~cm})$ & 33 & 3.0 \\
\hline 4層 $(5 \mathrm{~cm})$ & 33 & 2.7 \\
\hline 5層 $(6 \mathrm{~cm})$ & 33 & 4.1 \\
\hline
\end{tabular}

これらの水盤を氷厚方向に CASE1〜 4 は 4 層、CASE5 は 5 層に分けて切断し、それぞれの層の米を溶かし 分液ロートで原油と海水を分離した（図-4）。分離 した海水の重量を測定し、水盤中に浸透した原油量 を求めた。この結果より、各層の原油の含有率を求 めた（図一5)。

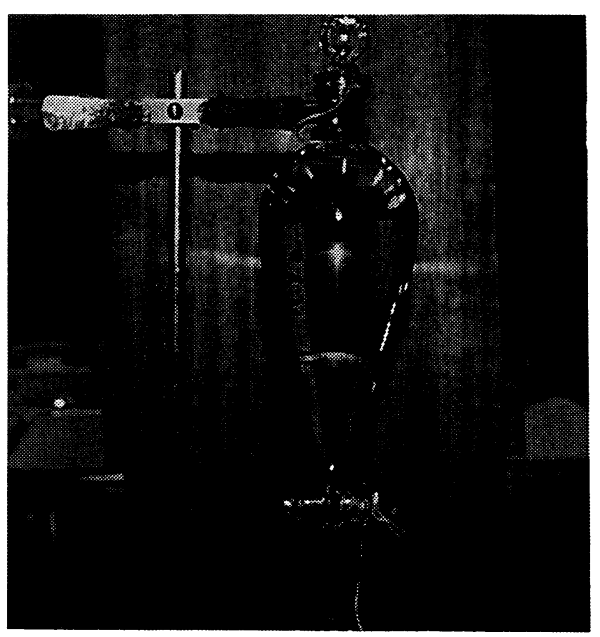

图-4 海水と原油の分離

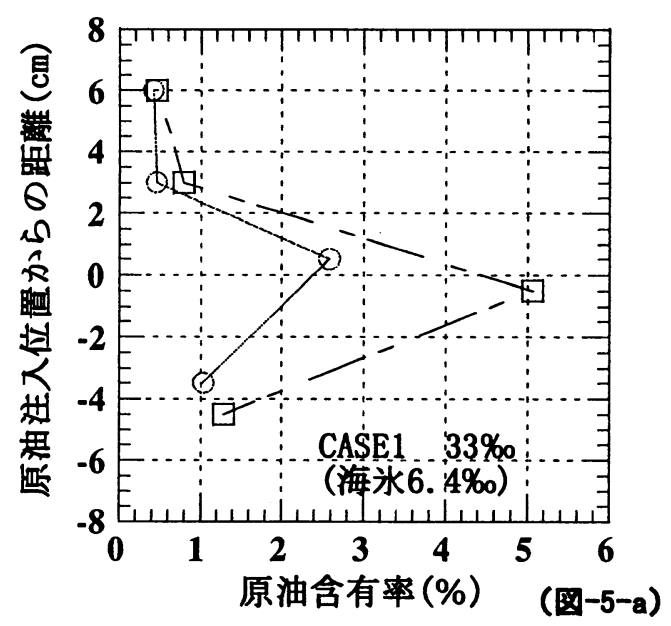



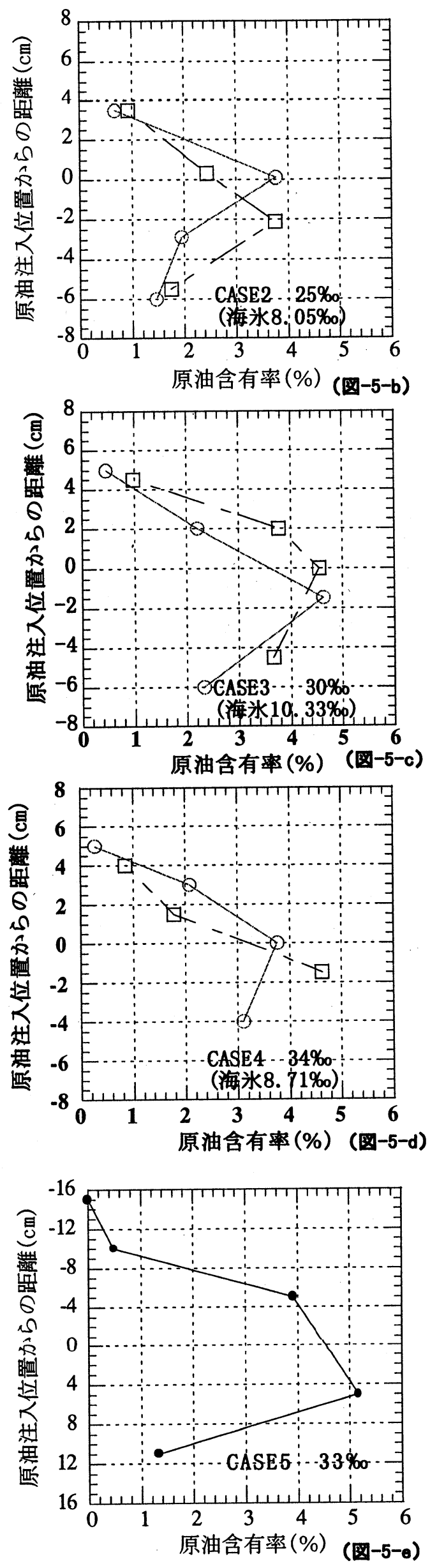

図-5 原油含有率の鉛直分布
これらの結果より、海水盤中にトラップされた原 油は氷盤中に渗透したが、上層にまで渗透していく ものは少なく $1 \%$ 以下であることがわかる。また、 今回の結果の水槽 B (CASE2〜4) での原油注入位置 よりも下層水盤の原油含有率が高いのは、水槽の高 さが小さかったため、原油注入後十分に氷盤が成長 できず結晶状になってしまい完全に原油がトラップ されなかったためと思われる(図一6)。

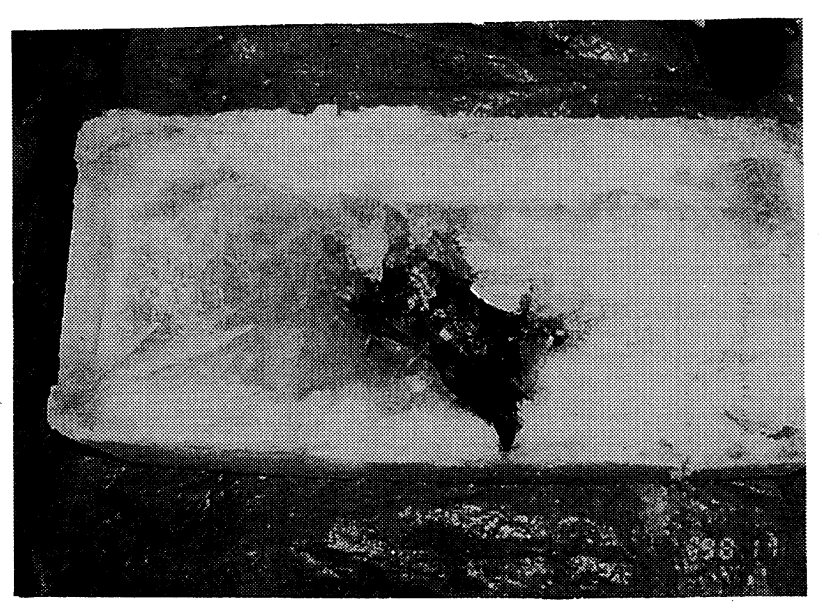

図一6 水槽から取り出した氷盤下面（水槽 B）

また、海水の透水係数は塩分濃度と氷温に依存す ることが過去の実験で明らかになっている。 本実験での水盤の透水係数と原油注入位置よりも上 層の原油含有率の関係を表-3、4 に示す。

\section{表－3 水盤の透水係数（CASE1～4）}

\begin{tabular}{|c|c|c|}
\hline & $\begin{array}{c}\text { 水盤塩分量 } \\
(\% 0)\end{array}$ & $\begin{array}{c}\text { 透水係数 } \\
\left(-5^{\circ} \mathrm{C}\right) \\
(\mathrm{cm} / \mathrm{sec})\end{array}$ \\
\hline CASE1 & 6.40 & 0.0013 \\
\hline CASE2 & 8.05 & 0.0022 \\
\hline CASE3 & 10.33 & 0.0035 \\
\hline CASE4 & 8.71 & 0.0026 \\
\hline
\end{tabular}

表－4 水盤の透水係数（CASE5）

\begin{tabular}{|c|c|r|r|}
\hline \multirow{2}{*}{ CASE5 } & \multirow{2}{*}{$\begin{array}{c}\text { 水盤塩分 } \\
\text { 濃度 }\end{array} \%$ 秀) } & \multicolumn{2}{|c|}{ 水係油注入時 } \\
\hline 1層 & 2.1 & 0.000012 & 水盤成長後 \\
\hline 2層 & 2.9 & 0.00000048 \\
\hline 3層 & 3.0 & 0.0002 & 0.0000038 \\
\hline 4層 & 2.7 & & 0.000055 \\
\hline 5層 & 4.1 & & 0.0006 \\
\hline
\end{tabular}


また、氷盤の透水係数と原油注入位置よりも上層の 原油含有率との関係を図ー7、8に示した。

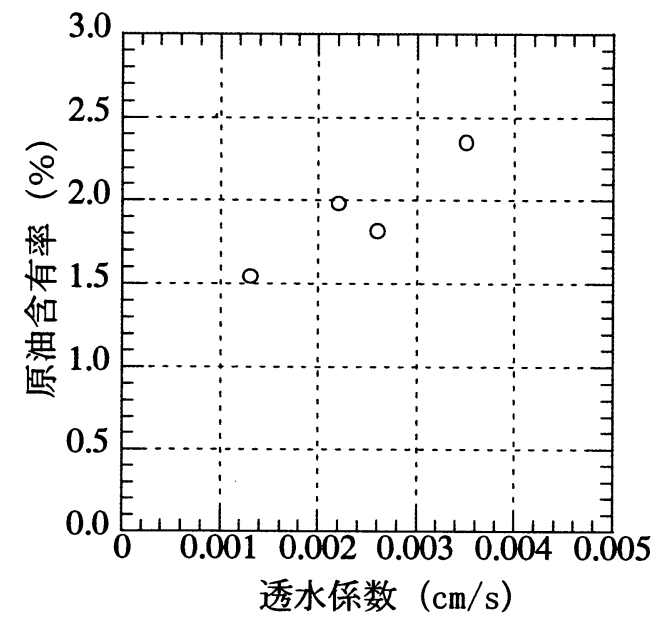

图一7 氷盤の透水係数と原油含有率の関係 (CASE1〜4)

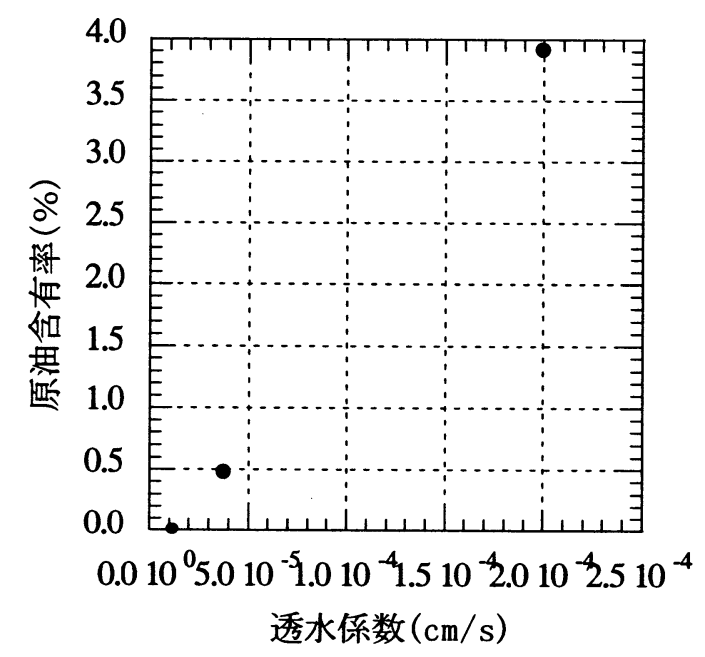

图-8 氷盤の透水係数と原油含有率の関係 (CASE5)

これより、海水盤の透水係数と原油注入位置より 上層の原油含有率には強い相関があることが明らか になった。

\section{（2）実釦 II}

実験 II として承盤への滲透速度を調べる実験を行 った。用いた水槽は透明のプラスチック製容器で、 この水槽に同一条件（海水塩分濃度 $30 \%$ 、室温 $\left.5^{\circ} \mathrm{C}\right)$ で海水盤を作成した。その水盤を切り出し再 び海水に浮かべ同時に一定量の原油（約 $100 \mathrm{ml}$ ）を 氷盤下面に注入した。注入後、時間を変えて氷盤を 取りだし氷盤中への渗透状態を調べた。

実験時の氷厚は $8 \sim 9 \mathrm{~cm}$ 程度であった。この水
盤を氷厚方向に上層から $1,2,3$ 層として切断した。 各層とも $3 \mathrm{~cm}$ 程度の厚さである。また、氷盤下面は 氷の成長途中の結晶の状態であり原油がその結晶の 間に付着していた。その部分を 4 層として原油の含 有量を測定した。原油の含有量を正確に測るため、 表面に付着している原油は低温の海水を用い、でき る限り洗い流してから測定した。測定結果を結果を 表一5 に示す。原油渗透割合とは原油注入量に対す る氷盤中への渗透量の割合である。原油沴透割合は 注入時の原油の密度を $0.9 \mathrm{~g} / \mathrm{cm}^{3}$ として求めた。

\section{表-5 経過時間と原油含有量·透水倸数·渗透割合}

\begin{tabular}{|c|c|c|c|c|}
\hline 経過時間 & 層 & $\begin{array}{c}\text { 含有量 } \\
(\mathrm{g})\end{array}$ & $\begin{array}{l}\text { 透水係数 } \\
(\mathrm{cm} / \mathrm{sec})\end{array}$ & $\begin{array}{c}\text { 沴透割合 } \\
(\%)\end{array}$ \\
\hline \multirow{4}{*}{$0.5 \mathrm{~h}$} & 1 & 0 & 0.0082 & \multirow{4}{*}{ 4. 19} \\
\hline & 2 & 0 & 0.0075 & \\
\hline & 3 & 3.77 & 0.0091 & \\
\hline & 4 & 4.08 & & \\
\hline \multirow{4}{*}{$1.5 \mathrm{~h}$} & 1 & 0 & 0.0086 & \multirow{4}{*}{8.71} \\
\hline & 2 & 0 & 0.0080 & \\
\hline & 3 & 7.84 & 0.0099 & \\
\hline & 4 & 4.29 & & \\
\hline \multirow{4}{*}{$3 \mathrm{~h}$} & 1 & 0 & 0.0093 & \multirow{4}{*}{6.67} \\
\hline & 2 & 0 & 0.0093 & \\
\hline & 3 & 6 & 0.0083 & \\
\hline & 4 & 6.53 & & \\
\hline \multirow{4}{*}{$6 \mathrm{~h}$} & 1 & 2.96 & 0.0089 & \multirow{4}{*}{8.38} \\
\hline & 2 & 2.09 & 0.0107 & \\
\hline & 3 & 2.49 & 0.0102 & \\
\hline & 4 & 5.01 & & \\
\hline \multirow{4}{*}{ 10. $3 \mathrm{~h}$} & 1 & 4.31 & 0.0093 & \multirow{4}{*}{12.09} \\
\hline & 2 & 4 & 0.0188 & \\
\hline & 3 & 2.57 & 0.0122 & \\
\hline & 4 & 6.97 & & \\
\hline \multirow{4}{*}{$15.2 \mathrm{~h}$} & 1 & 4.97 & 0.0086 & \multirow{4}{*}{12.0} \\
\hline & 2 & 4.5 & 0.0139 & \\
\hline & 3 & 1.37 & 0.0169 & \\
\hline & 4 & & & \\
\hline
\end{tabular}

この結果より、ほぼ 1 ～3 層の原油含有量は時間 とともに増加している傾向にある。しかし、氷盤中 の結晶の状態が等しくなく一個所のブラインに集中 的に浸透するなど、渗透の状態は一様ではなかった。

また、4 層の含有量が多いのは細かい結晶の間に 原油が入り込んでいるためである。 


\section{（3）実験 III}

実験吕として、透明のプラスチック製容器に $30 \%$ の海水を満たし、それぞれの結水開始時期を変え、 室温他の条件を同一にして氷盤を作成した。一定量 の原油（約 $100 \mathrm{~m} 1 ）$ を水盤下に注入し、一定時間お いた後、氷盤中への原油の渗透量を観察した。

氷厚は、 $5 \sim 10 \mathrm{~cm}$ 程度の 4 種類であった。 10 時間 経過した後取り出したが、本実験では測定に十分な 沴透は確認できなかった。

そのため、さらに 2 日ほど置いて渗透量を測定し た。この測定時は、実験 Iよりも時間を置いたため 完全に原油が氷盤中にトラップされた状態であった。 取り出した氷盤を原油注入位置より上層と下層に分 けて原油の含有量を測定した（図一9）。

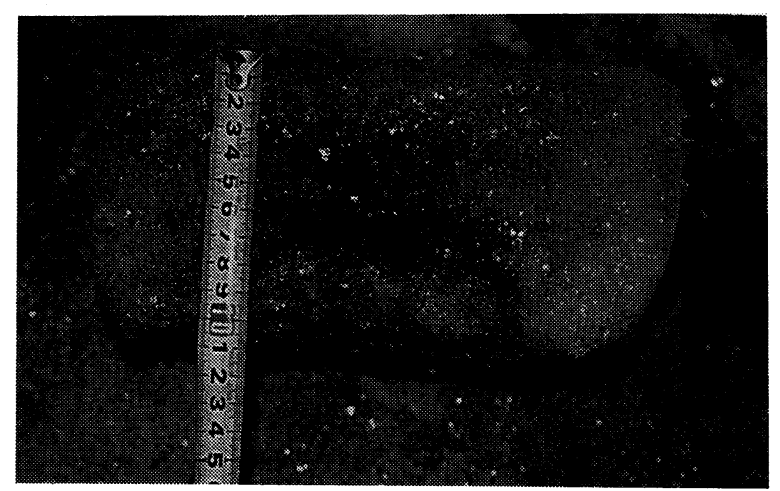

図一9 2 日後に取り出した氷盤

原油含有量の測定結果より注入原油に対する浸透 した原油の割合を求めた。今回も注入時の原油の密 度は $0.9 \mathrm{~g} / \mathrm{cm}^{3}$ として計算した。2 ケースについて測 定を行った結果を表一6に示す。

表－6 原油の含有量と渗透割合

\begin{tabular}{|l|l|r|r|}
\hline & & \multicolumn{1}{|c|}{$\begin{array}{c}\text { 含有量 } \\
(\mathrm{g})\end{array}$} & $\begin{array}{c}\text { 渗透割合 } \\
(\%)\end{array}$ \\
\hline \multirow{2}{*}{ CASE1 } & 上層 & 10.0 & 11 \\
\cline { 2 - 4 } & 下層 & 28.1 & 31 \\
\hline \multirow{2}{*}{ CASE2 } & 上層 & 5.0 & 6 \\
\cline { 2 - 4 } & 下層 & 13.0 & 14 \\
\hline
\end{tabular}

今回の実験で渗透量の割合で倍近い差が出た原因 として考えられるのは、上層と下層に分けた際に低 温の海水で水盤に付着した原油を洗い流し方に違い があったと思われる。

\section{3. 結䜽}

1）海水盤中にトラップされた原油は水盤中に滲透 したが、図一5 に示すように上層にまで渗透し ていくものは少なく 1\%以下であることがわか った。また、原油注入位置では水平方向にも浸 透していることが確認された。

2）原油の含有率は原油がトラップされた付近で約 3〜 5\%と一番多くなることが明らかになった。 また、注入位置より下層の注入後に結水した氷 中にも渗透が見られた。この原因は氷盤の成長 に伴い対象位置の水温は低下し、そのためブラ イン中の塩水が強度の弱い下層に向かって移動 することになるためと考えられる。

3）原油含有率と透水係数には図ー7、8より強い 相関が見られた。

4）承盤下に下方から連続的に原油が流出した場合、 流出原油は氷盤下で水平方向に拡散するが、そ の時、一部の原油は氷盤中に滲透するため、拡 散係数は淡水水等に較べて小さくなることが予 想される。

5）氷盤下に流出した原油の渗透割合は、実験 II、 IIIより $10 \%$ 前後になる事が明らかになった。

低温環境下では、トラップされた油層の下の海水も 結水し、海水中にトラップされることになる。よっ て、氷盤下に流出した原油は速やかに回収しないと 事実上回収不能となる可能性が高い。

なお、本研究は石油公団石油開発技術センターの 研究助成を受けた事を記す。

\section{素考文献}

1）佐伯浩、竹内貴弘、窪田太、五十嵐昇：海水盤 の透水係数に関する研究、海洋開発論文集、VOL. 1、 pp. 74-77、1985.

2）大塚夏彦・大島香織・石川博基·宇佐美宣拓・渡部 靖憲·佐伯浩 : 海永盤中にトラップされた原油の 変質過程、寒地技術論文・報告集 Vol. 14、 pp. 326-332、1998.

（1999. 4. 19. 受付） 